\title{
Predictors of orphan drug approval
}

\author{
Harald Heemstra \\ From 5th European Conference on Rare Diseases (ECRD 2010) \\ Krakow, Poland. 13-15 May 2010
}

\section{Objective}

To encourage the development of drugs for rare diseases, an orphan drug legislation has been introduced in the USA (1983) and in the EU (2000). Recent literature provides criticism on the slow development of orphan drugs in the EU. This study aims at identifying predictors for successful marketing authorisation of potential orphan drugs in the EU and the US.

\section{Methods}

Using publicly available data, the number of orphan designations and orphan drugs in the EU and the US was determined. A comparison between randomly selected authorised and a matched sample of not yet authorised orphan drug designations in the EU has been performed. Determinants in the study included characteristics of the indication, of the product and of the sponsor.

\section{Results}

More orphan drugs were developed in the US during the first ten years of the US Orphan Drug Act (1983-1992, $\mathrm{N}=73$ ) and during the first ten years of the EU Regulation on Orphan Medicinal products (2000-2009, N=112) than in the $\mathrm{EU}(2000-2009, \mathrm{~N}=59)$. Orphan drug approval was strongly associated with previous experiences of the sponsor in obtaining approval for another orphan drug $(\mathrm{OR}=17.3,95 \% \mathrm{CI}=5.6-53.1)$. Furthermore, existing synthetic entities compared to biotechnology products tended to have a higher likelihood of reaching approval status $(\mathrm{OR}=3.9,95 \% \mathrm{CI}=0.9-16.6)$.

\section{Conclusion}

This study showed that the experience of a company in developing orphan drugs is an important predictor for subsequent authorisation of other orphan drugs. The same applies for existing (synthetic) molecules, for

Correspondence: hheemstra@pharmerit.com

Pharmerit International, Bart Heeg, Marten Meesweg 107, 3068 AV

Rotterdam, The Netherlands which more knowledge is available. Companies or institutions wishing to develop an orphan drug should therefore seek experienced assistance and engage in dialogue with the regulatory authorities.

Published: 19 October 2010

doi:10.1186/1750-1172-5-S1-018

Cite this article as: Heemstra: Predictors of orphan drug approval.

Orphanet Journal of Rare Diseases 2010 5(Suppl 1):O18.
Submit your next manuscript to BioMed Central and take full advantage of:

- Convenient online submission

- Thorough peer review

- No space constraints or color figure charges

- Immediate publication on acceptance

- Inclusion in PubMed, CAS, Scopus and Google Scholar

- Research which is freely available for redistribution

Submit your manuscript at www.biomedcentral.com/submit 